\title{
Growing with wheat and barley rusts for three decades ${ }^{*}$
}

\author{
S.C. BHARDWAJ \\ ICAR-Indian Institute of Wheat and Barley Research, Regional Station, Flowerdale, Shimla 171002 , \\ Himachal Pradesh, India
}

Received: 10 February 2017/ Accepted: 20 February 2017/ Published online: 23 March 2017 (C) Indian Phytopathological Society 2017

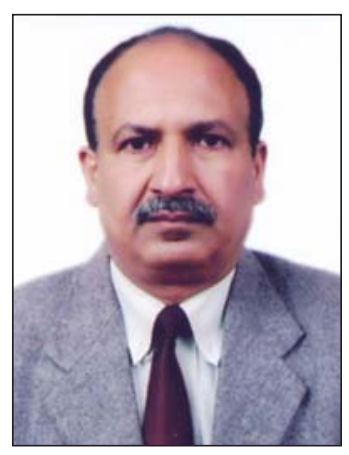

Keywords: Barley, epidemiology, pathotypes, Puccinia spp., rust, wheat

I feel honoured and elated for being conferred S.N. Dasgupta memorial award. I am grateful to the Indian Phytopathological Society to bestow this honour upon me which is named after one of the great Scientists of all the times. Dr. Dasgupta belonged to a family of distinguished people. He did pioneer research on physiological plant pathology, was an excellent Fungal taxonomist who rose to become the Vice Chancellor of Kalyani University, a position he served for two terms. I think he would have been very happy today to see that I would be discussing very important disease rust and sharing my experience with this august gathering, on ways and means to secure wheat. This crop is synonym to economic health and nutritional security of many countries with India no exception. Today we remember Dr. Dasgupta for the work done by him for the progress of biosciences and this lecture is a tribute to the great soul.

Wheat is a staple diet, protein source and second largest produced cereal in the world. Accounting for a one fifth of humanity's food, wheat provides $21 \%$ of the food calories and $20 \%$ of the protein for more than 4.5 billion people in 94 developing countries. It contributes to $30 \%$ of the world's edible dry and $60 \%$ of the daily calorie intake. Indian agriculture contributes about $14.1 \%$ to the GDP and employs more than $58.2 \%$ of the population. Current wheat production of India is 93.50 million tonnes from an area of 30.23 million hectares with an average production of $30.93 \mathrm{Q}$ per hectare. With a change in the food habits, there has been increasing demand for wheat in the recent past. Agriculture today is plagued with many hurdles. Soils have become sick, there are new biotic, abiotic threats, there is indiscriminate use of chemicals, water sources have

\footnotetext{
${ }^{*}$ S.N. Dasgupta Memorial Award Lecture, delivered at 69th Annual Meeting of Indian Phytopathological Society and National Symposium on "Diagnosis of and management of plant diseases: Integrated approaches and recent trends". January 9-11, 2017 at ICAR Complex for NEH Region, Umiam, Shillong, Meghalaya Email: scbfdl@ hotmail.com
}

become scant, inputs are costly and there is decrease in net profits. Biggest challenge for us is to produce 120 million tonnes of wheat by 2050 to feed 1.7 billion people of India. Wheat production is prone to many biotic and abiotic constraints. Rusts are historic, threatening and major biotic constraints of wheat worldwide. Stripe rust is a challenge to wheat production in west Asia, southern Africa, the Far East (China), South America and northern Europe. Leaf rust caused more serious losses in south Asia, North Africa, Southeast Asia and South America. Black rust has been traditionally important in North America, Australasia, northern Africa, South Africa and, to some extent, Europe (Mc Intosh et al., 1995). Depending upon the wheat cultivar and stage of growth, wheat rust epidemics can inflict losses up to $100 \%$ due to stripe and stem rusts whereas $40 \%$ in leaf rust (Anonymous, 1992).

Specialization of parasitism in black rust was demonstrated by Dr. E.C. Stakman while working in Cereal Rust Laboratory at Minnesota U.S.A. in the second decade of twentieth century. Races were identified on distinguishing hosts called differentials. Likewise work for other wheat rusts was published in the third decade. Wheat rust research in India started around 1922 with the efforts of Dr. Karam Chand Mehta of Agra College, Agra, who initially funded the programme using his own savings and selected four places. Among Agra, Almora, Muree (now in Pakistan) and Shimla, he selected the later for its suitability for growing wheat and rusts throughout the year with little efforts. Later on Imperial Council of Agriculture Research (British India) granted funds in 1930. His landmark contributions have been to investigate the recurrence of wheat rusts in India, non functional nature of alternate hosts under Indian conditions, wheat rust surveys, race analyses, evaluation for rust resistance and initiation of systematic wheat rust research in India (Mehta, 1940,1952). A detailed account of wheat rusts has been published recently (Bhardwaj et al., 2016a). 
The outbreaks of three rusts of wheat have occurred periodically in different parts of the world. Break down of yellow rust resistance Yr9 in 1986 in Western Asia and subsequently in other parts of the world was a serious challenge to our efforts to combat these pathogens. In 1998, strong wheat programme of USA also had a setback due to high incidence of yellow rust in great plains. The gravity of situation necessitated issuing of emergency label for Folicur for use on wheat and barley in the state of Washington and fungicide Tilt was also recommended for use up to heading stage. There were three consecutive epidemics of yellow rust between 1994-1996 in Pakistan and varieties based on resistance of $Y$ r9 (1BL.1RS translocation/substitution) derived from rye became susceptible to yellow rust.

Black rust of wheat was a forgotten disease for sixty years till 1998 when virulence on Sr31 (1B.1R translocation/substitution) designated as Ug99 was identified from Uganda (Pretorius et al., 2000). This gene was known to confer black rust resistance in wheat material covering more than $40 \%$ area world over. Since then ten variants of Ug99 have been reported. To date, 10 variants of the Ug99 race group have been reported from 13 countries, i.e., Uganda, Kenya, Egypt, Ethiopia, Sudan, Tanzania, Eritrea, Rwanda, South Africa, Zimbabwe, Mozambique, Yemen, and Iran (Patpour et al., 2016). So far Sr31 types of virulences have not been reported in India. Weighing all the pros and cons, it may not be a threat for the Western Asia (Nagarajan, 2012) but occurrence of independent mutation for Sr31 locally in the much prone Peninsular and Central India cannot be ruled out (Bhardwaj et al., 2014).

These facts endorse the statement of noble laureate Dr. Norman Borlaug's that rust never sleeps. Definitely, wheat rusts remain active even when the entire world sleeps. Among the three wheat rusts, yellow (stripe) rust (Puccinia striiformis Westend.) is a threat to about 1011 million hectare of wheat being cultivated in cool climate of Northern India whereas 7-8 million hectares of Peninsular, Central and adjoining parts of Northern India are prone to black (stem) rust ( $P$. graminis tritici) epidemic. Brown (leaf) rust ( $P$. triticina) is a disease of all the wheat growing areas of India.

Historical account of wheat rust epidemics in India has been given by Nagarajan and Joshi (1975). Epidemics had been reported in Jabalpur as early as 1786 and subsequently in 1805, 1827, 1828-29, 183132. Later on rust epidemics occurred in the Central Province during 1879 and 1894-95. Einkorn wheat had a severe attack of black rust in May 1907. During 194647 epidemic of black rust occurred in central India and in 1948-49 in southern district of Bombay state. In the main wheat producing belt of India rust epidemics have occurred around 1843 at Delhi and during 1884 and 1895 at Allahabad, Banaras and Jhansi. Later on in 1905 rust epidemic was reported to have occurred in Punjab and sub mountainous regions of Gorakhpur. Another report of yellow rust epidemic in Indo Gangetic plains is of 191011. Both brown and yellow rusts caused losses in Western Uttar Pradesh between 1971-73. Another epidemic of brown rust occurred in 1993 in about 4 million hectares of North Western India.

Mehta (1952) reported a total loss of about Rs. 60 million annually in wheat and barley. According to Prasada (1960) nearly one million tonnes of wheat costing about Rs. 392 million were damaged during 195859. The gravity of damage can be seen from the statement that in Bihar due to epidemic in 1956-57, only half maund of grain per acre was harvested as against the lowest average yield of 9 maunds per acre. According to our estimates by avoiding meagre $5 \%$ losses due to rusts, there was saving of Rs. 39,200 million during 19992000 in India. Avoidance of epidemics alone in northern India in 1994-96 which devastated wheat crop in Pakistan, there was saving of Rs. 100,000 million per annum (Bhardwaj et al., 2009).

\section{Epidemiology of wheat rusts}

Under Indian conditions alternate hosts of wheat rusts are not functional (Mehta, 1929 \& 1940). Survival and perpetuation of wheat rusts over the seasons, therefore, occur in the form of uredospores (called as repeating spores) in the hills on self-sown plants and summer crop. In fact, alternate hosts are of no consequence in the recurrence of three wheat rusts in India. Mehta (1940) concluded on the basis of the facts given below that the alternate hosts for black and brown rusts are nonfunctional under Indian conditions:

i) There is scarcity of germinable teleuto-material available from the crops over the greater part of the area under wheat even in hills due to their formation in or subsequent exposure to the hottest part of the year (April-June).

ii) Viable teliospores were likely to be formed on crops at higher altitudes. If at all these germinated and infected barberries in monsoons, such infections would be of little consequence as there was hardly any crop at that time.

iii) Black rust had been found to break out in plains as early as December-January, 3-4 months prior to the period of earliest possible infection of barberries in the hills and there were none in the plains.

iv) There was no case on record, nor any evidence could be obtained during the studies, of an outbreak of black rust starting from barberries.

v) At higher altitude rust will not be able to spread from plant to plant during winters because of severe cold.

So far, four categories of aecial stages have been recorded on Berberis but are connected with the hosts other than wheat, as given below:

1. An aecial stage commonly present in Shimla hills has been connected with Agropyron semicostatum Nees and is $P$. graminis f. sp. agropyrii.

2. Aecial stage on Berberis jaeschkeana C.K. Sch. has been connected with Poa nemoralis and named as $P$. poae-nemoralis Otth. 
3. The third aecial stage of Berberis in Shimla is connected with Brachypodium sylvaticum (Huds.) Beauv. being P. brachypodii .

4. Aecidium montanum Butler which is frequently observed in Shimla, Kumaon hills and Nepal could not be related to $P$. graminis tritici and has been retained as Aecidium montanum.

In the Indo-Gangetic plains during the warm post harvest summer months, the rust pathogens are eliminated due to high temperature followed by rainy season. There is no local inoculum left in the Indo Gangetic plains to cause fresh infections during the succeeding wheat season. The rust pathogens survive in the form of uredospores in Himalayas in North either on offseason wheat crop, volunteer plants or green bridges and in the Nilgiri and Pulney hills in south India where wheat is available around the year about $1500 \mathrm{M}$ altitude. These areas serve as the source of rust inoculum for the initial rust infection in the plains (Mehta, 1952).

The rusts of wheat are polymorphic in nature and they produce five spore stages for completion of life cycle. Two stages of the rust fungus (uredial and telial) are produced on wheat and other two stages (Pycnial and aecial) are produced on Berberis or Thalictrum. While it has been shown in USA and European countries that alternate hosts are the main sources of inoculum for the onset of the disease on wheat but in India they do not appear to play any role in perpetuation. Dr. E.J. Butler, a pioneer in Plant Pathology in India raised doubts on the role of alternate host in the perpetuation of black rust in India. Butler's investigations were followed by the classical work of Prof. K.C. Mehta on cereal rusts at Agra College, Agra and Rust Research Laboratory, Shimla from 1922-1950. Thalictrum species are non-functional as far as perpetuation of brown rust is concerned. The earlier recorded aecial stage of Thalictrum javanicum of in Shimla hills was connected with Puccinia persistens of Agropyron semicostatum. Other alternate hosts viz. Isopyrum fumaroides and Clematis spp. are also not functional in India.

In absence of functional alternate hosts, wheat rusts survive through uredospores which act as repeating spores. Therefore, rusts are carried from one season to another with the help of uredospores which survive on off season wheat or self-sown wheat or most probably some grass or other hosts in the catchment areas of plains of India. The annual recurrence of three rusts in the plains was investigated by Mehta (1952). He opined that dissemination of rusts that occurs in India, results from wheat crop in hills and plains and prevailing climate of these regions. Mehta visualized that the wheat crop in the Nilgiri and Pulney hills in South is cultivated round the year. The rusts over summer in their uredial stage in the cool climate of hills on wheat crop, self-sown plants and ratoon tillers. Likewise the Himalayan ranges covering India and Nepal has several valleys and gorges where wheat is grown during April-May and harvested in September-October. Shivalik ranges, Hindukush Mountain and North Western Frontier Province have been considered to the active foci of infection for dissemination of rust uredospores to Indo-Gangetic plains.

Although several grasses as collateral host, such as Bromus colaratus, B. carinatus, B. mollis, B. japonicus B. patulus, Hordeum distichem, H. murinum, $H$. stenostachys, Lolium perenne, Brachypodium sylvaticum, Hilaria jamessi, Aegilops squarrosa, $A$. ventricosa and $A$. trigecilis have also been recorded to be susceptible to wheat rusts but they are not considered significantly important in the annual recurrence of rusts in the plains. Mehta made outstanding contributions on epidemiology of wheat rusts in India and published classical scientific monograph tiled "Further studies on cereal rusts in India" in two parts. In addition the flora of black and brown rusts in the states of Karnataka and Maharashtra is different to that of Nilgiri hills. Therefore, it is evident that some additional foci of infection in these states do exist (Bhardwaj et al., 1989). When India ushered into an era of Mexican dwarf wheat in 1967, the Indian Agricultural Research Institute, New Delhi initiated a National Wheat disease Survey and surveillance Programme which rejuvenated the interest in the epidemiological studies of wheat rusts in the country. This disease monitoring system by mobile surveys supplemented with trap nurseries and weather satellites has provided useful information on epidemiology of wheat rusts and development of Puccinia path (Nagarajan and Joshi, 1980).

Mehta $(1940,1952)$ suggested that brown rust of wheat spreads both from South and North Indian hills. This view is supported by various studies done subsequently (Nagarajan and Joshi, 1985). It has been demonstrated that the first build-up of brown rust, like black rust takes place in the plains of Karanataka in South India, generally in the last week of December. Dissemination of brown rust from Southern foci to Central Peninsular India is like that of black rust and appearance of the disease can be predicted on the basis of Indian black rust rules. At the same time the infection also establishes in Bihar in North Eastern region of the country. The rust population from Southern region moves northwards towards Maharashtra and Madhya Pradesh and other population moves from Northern region towards south. Finally both the populations, moving in opposite directions merge into each other. The investigations have also revealed that inoculum of $P$. triticina available in Central Nepal becomes wind borne and arrive in the foot hills and adjoining plants of Bihar sometime during Christmas. The uredospores of brown rust land on the wheat seedlings and the dew on leaves favours infection and establishment of primary foci in North East region. On the other hand few isolated pockets of infection along the foot hills of Jammu and Kashmir, Punjab, Himachal Pradesh and Western Uttar Pradesh also appear but they remain less active because of cool climate. In comparison to North-western region, the weather of North East sector is warmer which enables the brown rust to multiply many times more. Therefore, by early February with rise in temperature, the less active 
pockets of infection along the foot hills of Uttrakhand, Himachal Pradesh, Punjab and Jammu region of J\& K also become active and spread slowly towards NorthEast. Finally, the actively spreading population of uredospores from North East gets mixed with the population from North West. Thereafter, the two migrating populations are indistinguishable.

Nagarajan et al. (1978) documented that the uredospores of wheat brown rust from Northern region are also carried away by Western disturbances. This observation suggests that if more Western disturbances accompanied by frequent rains occurring in North India, there is apparently good chance for the spread and built up of brown rust in North Western region leading to an epidemic.

The life cycle of Puccinia striiformis remained a mystery because the alternate host has never been identified until the work of Jin et al. (2010). Inoculation of grasses using aeciospores from naturally infected Berberis chinensis and $B$. Koreana resulted in infection on Poa pratensis, producing uredia typical of yellow rust caused by $P$. striiformis. Analyses using real-time polymerase chain reaction and DNA sequence confirmed the rust fungus as $P$. striiformis. Pycnia and aecia were produced on B. chinensis, B. holstii, B. koreana, and $B$. vulgaris after inoculation using germinating telia of $P$. striiformis f. sp. tritici. Wheat inoculated with aeciospores from $B$. chinensis resulted in uredia, which demonstrated that Berberis spp. also served as alternate hosts for the wheat yellow rust pathogen. The elucidation of the complete life history for $P$. striiformis $\mathrm{f}$. $\mathrm{sp}$. tritici has provided a powerful tool to rapidly advance our knowledge of the genetics of this rust fungus, and will lead to the development of improved strategies.

Following the methodology of Jin et al. (2010), conducted further studies on infecting wheat by Berberis aeciospores during 2008-16. Over the period took aeciospores from at least 10 species of Berberis from the hills of Jammu \& Kashmir, Himachal Pradesh and Nepal. Didn't get any infection on wheat. Therefore, it is again clear and proved beyond doubt that Berberis or any known alternate host do not play any role in the epidemiology of wheat rusts in India. In the meantime, collected various hosts around the wheat fields where yellow rust was appeared every year were collected. These samples collected in regular and off-season were screened against yellow rust specific markers but results were negative. Infection of grass rusts on wheat could get but in most of the cases Koch's postulates were not proved and in others, it is being studied.

In the absence of a functional alternate host, in India the primary inoculum for the Indo Gangetic plains comes each year from the array of Himalayan hills, where it survives on volunteer plants or summer crop in the form of uredospores. The role of collateral hosts like species of Agropyron, Aegilopes, Bromus, Hordeum and other grasses in the epidemiology of wheat rusts is less clear in the annual recurrence of the disease.
There had been intriguing and mind boggling situation with respect to epidemiology of wheat rusts in India which is evident from the facts given below:

i. Practically there is little or no wheat cultivation in higher hills in North and Southern India. In summer/ off-season crop we get a very mild infection of wheat rusts. Impact of climate change is visible as we have not observed yellow rust in Nilgiri hills for the last so many years.

ii. In yellow rust of wheat new pathotypes have been reported identified from Western Punjab or foot hills of Himachal Pradesh and have spread further to other areas after 3-7 years.

iii. Studies by using specific primers for wheat yellow rust on the vegetation in and around the areas where the disease is encountered every year, yielded negative signs.

iv. Climate/ cultivar grown in area over a period have definitely influenced the racial pattern. Pathotype 46 S119 of wheat yellow rust was identified from Gurdaspur (Punjab) in 1996 and it became predominant in 1999-2000 season and ruled the scene up to 2006-07. Subsequently, pathotype $78 S 84$ was detected in 2001 and it displaced $46 S 119$ in 2007-08. In North western India, pathotype 78584 dominated the scene of yellow rust flora up to 201011 when its population was $55 \%$ whereas that of $46 S 119$ was $42 \%$. During this period PBW343 was being cultivated over a large area. HD2967 replaced the variety PBW343 and consequently 46S119 became predominant since 2011-12. These pathotypes were recorded in plains of North western India, then spread to other areas slowly. Occurrence of these pathotypes was observed in hills after 5-7 years. Their movement path were very much evidents from our pathotype distribution maps. It is also evident that a pathotype appears, disappears and reappears. Since 2014, many new pathotypes have been observed by us at IIWBR, Flowerdale, Shimla, a centre devoted exclusively for wheat and barley rust research in South Asia.

v. One million dollar question is that owing to the prevailing high temperature in the plains of India and rainy season all the uredosporic inoculum of wheat rust pathogens is destroyed but there is recurrence of wheat rusts every year? The question remains of equal value and unanswered in Australia, New Zealand and other countries where alternate hosts are not known to be functional. To find out how the wheat rusts survive, trap plot nurseries were planted for five Kharif seasons in Himachal Pradesh, Jammu \& Kashmir, Punjab and Uttarakhand at ten locations. The nursery didn't survive in Kharif season except for Shimla where only brown rust for the last ten years and the pathotypes identified are those which occur in regular crop. Not withstanding the fact, yellow rust occurs every year. Further, the occurrence of yellow rust is first recorded invariably in Ropar area of Punjab, adjoining Kangra \& Una 
districts of Himachal Pradesh and Yamunanagar area of Haryana. To get some clue, chased the rusts of grasses. The rust on grasses was found hibernate twice in the year and becomes active twice. In severe summer months April to July, yellow rust on grasses is not visible and so is true from December to February. Interestingly, rust spores can be seen on these plants from March to June and August to November. To conclude, it can be said that the mycelium of this obligate parasite remains within the host tissue, however, visible symptoms on these grass plants occur only when conditions for plant growth become favourable.

From the aforesaid facts it can be concluded that yellow rust of wheat is surviving in different pockets of Nothern India (both plains and foot hills) or may be adjoining wheat growing areas of Pakistan and spreads locally by limiting its spread to few kilometres. It contradicts the prevailing theory of hills to plains movement of wheat rusts in India. Another limiting factor for long distance spread of yellow rust is the prevailing low temperature in Northern India during December and January. Moreover based on avirulence/virulence structure of Indian pathotypes of $P$. striiformis, its distance from West Asian and South African population, it is evident that mutation, selection and local adaptation to resistant genotypes are prime reasons for evolution of new virulences in India and it is contrary to the hypothesis of incursions from Western Asia, South Africa and Eastern Europe. We are working on further aspects and hope to make some headway shortly.

\section{Monitoring of wheat rusts}

During the green revolution when Mexican dwarf wheat varieties carrying Norin-10 gene were introduced in India, it was speculated that these varieties might get succumbed by rusts. Hence, a close disease monitoring system was founded in 1967. This disease monitoring system provided useful information on performance of newly evolved varieties and also provided good information on rust epidemiological aspects. The ground monitoring was done by mobile surveys and the information generated was supplemented with Disease monitoring nurseries and satellite information as given below:

i. Mobile surveys: Mobile surveys were conducted in Northern and Central India by classifying into different zones. Fixed routes were followed to monitor the disease after every $20 \mathrm{Kms}$.

ii. Disease Monitoring Nurseries: A large number of trap nurseries comprising of some highly susceptible genotypes, commercial cultivars, newly released cultivars, etc. are planted for trapping the rust virulences.

iii. Use of satellite for disease survey: Satellite television cloud photographs (STPC) have been made to monitor the wheat rusts in India (Nagarajan and Singh, 1973, Nagarajan and Joshi, 1980). The infrared images of wheat satellite corresponding to the ground level disease incidence were obtained. Nagarajan and Singh (1973) monitored the rust spores using rain water sampler. They concluded that in addition to wind, the inoculum of black and brown rusts that is available in the south Indian hills is carried further by tropical cyclones and is deposited along with rain over wheat crop in Peninsular and Central India.

\section{Evolution of new pathotypes}

Generally new pathotypes in wheat rusts evolve through sexual reproduction on alternate host. However, in absence of functional alternate hosts, new virulent forms in India mostly arise through mutations. Genes for virulence in the pathogen are recessive. Recessive mutations are more common than the dominant ones and are of the order of $10^{-5}-10^{-6}$. Since wheat rusts are dikaryotic, a double mutant would be needed which would be of order of $10^{-10}-10^{-12}$ (Knott, 1989). Though the new pathotypes evolve through the gain in virulence (forward mutation), however, recently loss of virulence (reverse mutations) have been recorded on Lr20, Lr2a and Lr2C (Bhardwaj et al., 2010; Bhardwaj, 2013). Many useful resistance genes like $L r 26, L r 9, L r 19$ and $L r 28$ have been rendered susceptible over the years (Nayar et al., 1991, 2003a; Bhardwaj et al., 2005, 2010). In recent surveys 37 pathotypes have been reported to occur in Puccinia triticina during 2009-2013 (Bhardwaj et al., 2016). Likewise Sr24 (Bhardwaj et al., 1990) and Sr25 (Jain et al., 2009) and Yr9 (Prashar et al., 2007) have been rendered susceptible in India. In some cases somatic hybridization is also known to give rise to new pathotypes (Bhardwaj et al., 2006).

Performance of SAARC wheat disease monitoring nursery in Pakistan and Afghanistan indicate differences in the flora of these countries when compared with that of India. Most of the lines supported moderate yellow rust in these countries, whereas in India, corresponding infection was more than $20 \mathrm{~S}$ at most of the locations. Frequency of these pathotypes keeps on changing with the climatic conditions and type of variety. Pathotype 46 S119, identified in 1996 remained predominant up to 2004-05 whereas later on $78 S 84$ was more widespread up to 2011, with the replacement of PBW343 proportion of 78S84 declined to 25\% whereas 465119 increased in frequency to $67 \%$ in 2013 (Unpublished). Therefore, the spread of inoculums generally occurs around the bordering areas of Western India and there is no exotic introduction. Moreover our pathotypes of both brown and black rusts appear to be different to other countries (Bhardwaj et al., 2016; Jain et al., 2013).

Trans-border movement of yellow rust inoculum is ruled out as four of the predominant pathotypes of $P$. striiformis in South Africa are virulent to $Y r 11$, one to Yr14 (6E16A), none on Clement (Yr2, 9, 25, Cle) whereas Yr11, 14 and Clement are resistant to yellow rust in India so far. Secondly in Western Asia, Clement, Heines VII, Suwon92X Omar are susceptible to 3 predominant pathotypes, whereas in India, we do not have any 
pathotype with that type of virulence structure (Prashar et al., 2015).

\section{Pathotype identification systems}

Over the years, pathotype analyses have changed from classic differentials of Stakman (Stakman et al., 1962) to Near Isogenic lines based. Depending upon the existing wheat rust racial flora, different countries developed their own systems for analysis and race designations. Owing to different evolutionary lineages, it was not possible to have a common identification system of pathotype identification. However, all the identification systems can be decoded and comparisons can be made. Researchers monitoring virulence frequencies are primarily interested in knowing which resistance genes or combinations are still effective for use in breeding programs. Other investigators and regions may be interested in virulence frequencies, virulence combinations, race frequencies, evolution, and diversity of Puccinia species on wheat. In the USA and Canada, a series of 20 and 16 near isogenic lines mostly in Thatcher background are used as differentials. In North America, differentials are grouped in 5 sets of 4 lines. When the four lines are classified for resistance or susceptibility, there are 16 possible combinations. These combinations are coded from B to T omitting the vowels. The pathogenicity of a race is coded using five letters, each indicating its pathogenicity on one set. For example, code $B B B B B$ indicates that all 20 differentials are resistant; whereas TTTTT indicates all 20 differentials are susceptible. Provision is made for supplementary differential sets, as currently used in Mexico, the USA, on a global basis, and other countries. In Europe, many systems of reporting races have been used, including an octal notation. Scientists in Nepal, Bangladesh, and Pakistan and other countries have their own systems, but races are reported using the North American code. However, United Kingdom and India had a binomial system of race nomenclature (Nagarajan et al., 1983), likewise South Africa and Australia have their own systems of pathotype designation.

\section{Interaction between host and pathogen}

Wheat rusts are model pathogens and have been very widely studied. Wheat-rust system is a very predictable and though biological but totally mathematical in behaviour (Bhardwaj, 2013). Wheat rusts follow the Flor's gene for gene model. Wheat rusts have continuously attracted the attention of Pathologists and Wheat Breeders because of their potential to cause huge losses, interesting genetics, ease to study host pathogen interaction and precise management tools. In an experiment on inheritance of yellow rust resistance in wheat cultivar Rivet, Biffen (1905) found the $F_{1}$ to be susceptible, and in $F_{2}$ segregation of 64:195 immune: susceptible. This landmark discovery that resistance to yellow rust in wheat is inherited in Mendelian fashion, opened new vistas in genetics of resistance and led to the systematic breeding for disease resistance.
Working with flax rust (Melampsora lini Desm.) and its host, flax (Linum usitatissimum), Flor (1942) was first to study both the inheritance of pathogencity and host response. Based on his studies he developed gene-forgene hypothesis (Flor, 1971). The hypothesis was further conceptualized by Person et al. (1962). They mentioned that "A gene for gene relationship exists when the presence of a gene in one population is contingent on the continued presence of a gene in another population and by which the presence or absence of the relevant gene in either organism may be recognized".

Gene-for-gene systems have evolved through a series of steps in evolution of each. Therefore, if a host is resistant to pathogen, a virulent mutant would have an advantage over avirulent. Likewise if a host is susceptible to a pathogen, a resistant mutant in host would be at advantage. Genetic analyses have indicated that resistance to rusts in wheat is controlled generally by dominant genes and virulence in pathogen is due to recessive genes (or avirulence is controlled by dominant genes in pathogen). Resistance and avirulence are dominant and they result from active gene product from avirulent pathogen. In genetic study on PBW343, a predominant wheat variety of Northern India, it was revealed that resistance to black, brown, yellow rusts is being controlled by dominant genes (Datta, et al., 2010). Likewise resistance of HS 424 to rusts is also governed by dominant genes (Datta et al., 2007). In cases where resistance is controlled by recessive genes, it may involve dosage effect and may require 2 or 3 dosages for an active gene product. Resistance in some cases is also controlled by recessive genes. Resistance of Agra Local to a pathotype of Puccinia triticina is controlled by 2 recessive resistance genes. One of these resistance genes was present in IWP94 also (Datta et al., 2008). Incompatibility (resistance) is a recognition process which results from a resistant host and avirulent pathogen. The infection type produced as a result of pathogen attacking a host is a product of two genetic systems. For a single pair of genes (assuming that homozygotes occur), interaction can be illustrated as shown in Table 1. Only one set, RR/PP, results in resistant (low infection type).

Table 1. Gene for gene relationship

\begin{tabular}{lll}
\hline Pathogen & \multicolumn{2}{c}{ Host } \\
\cline { 2 - 3 } & $\mathrm{RR}$ & $\mathrm{Rr}$ \\
\hline $\mathrm{PP}$ & Resistant & Susceptible \\
$\mathrm{pp}$ & Susceptible & Susceptible \\
\hline
\end{tabular}

The host carries a gene for resistance for which the pathogen does not carry the corresponding gene for virulence. There occurs a specificity in combinations involving the genes that are normally dominant, $R$ and $P$. Any one of the three other combinations, RR/pp, rr/PP, $\mathrm{rr} / \mathrm{pp}$ would result in susceptibility or compatible reaction.

\section{Functioning of Gene-for-Gene relationships in the field}

Wheat breeders and farmers lead to evolution of genotype in the field. Breeders develop varieties and 
Farmers have choice to go for cultivation of a desirable type, which results in directional selection on the pathogen. An introduced resistance gene succumbs to a new virulence rapidly. If a genotype is being cultivated over a large area, it may lead to epiphytotic. Thus with the built up of resistance, rust pathogens also overcome the barrier and progress of virulence occurs in the rust pathogen. Even the transgenic rust resistance derived from rye (Secale cereal) which was very effective against all the wheat rusts $(L r 26 / S r 31 / Y r 9)$ was rendered susceptible one by one. In case of brown rust of wheat, there were no pathotypes which had virulence for $L r 26$ but within few years many virulent pathotypes of $P$. triticina have appeared in India. There had been a matching gain in virulence against built up resistance in wheat in India which has resulted in more virulent pathotypes (Bhardwaj et al., 2016a).

\section{Factors influencing expression of wheat- rust interaction}

The characteristic feature of wheat-rust interaction is a phenotype which may be resistant or susceptible. Host has resistance or susceptibility whereas pathogen has pathogenicity which may be avirulence or virulence and net result is resistance or susceptibility. Categories 0-2 are resistant, $2+=$ moderately resistant, $3=$ Moderately susceptible and 33+, 3+ are categorized as susceptible. Many factors like type of pathotypes, light, temperature, genetic background and stage of plant are known to influence the host pathogen interaction. Some of the rust resistance genes may be effective in one country but totally ineffective in other countries. A partially dominant resistance gene conferred resistance to pathotype 121R127 at high temperature (Datta et al., 2008). Some types of rust resistance become effective at high temperature whereas others at low temperature. Resistance of Lr12, Lr13, Lr16, Lr17, Lr21, Lr22a, Lr22b, $L r 34, L r 35, L r 36$ and $L r 37$ is also effective at adult plant stage (Nayar et al., 2004). Saini et al. (2002) have also reported novel hypersensitive adult plant resistance genes Lr48 and Lr49.

\section{Using infection type response to postulate rust resistance genes}

Host pathogen systems are complementary to each other. Based on the gene for gene hypothesis, knowing the avirulence/ virulence structure of rusts, rust resistance genes can be inferred. Popularly called as gene matching technique, is used by wheat rust labs to characterize rust resistance genes (Browder, 1973). Keeping in view the influence of light and temperature on the wheat-rust interaction, manual gene matching is the accepted and followed method for rust resistance gene characterization. In this method, the genotype/ cultivar under gene postulation is planted along with isogenic lines having known resistance genes and challenged separately at seedling stage with an array of virulences of a rust pathogen. Rust reactions are recorded as per Stakman et al. (1962) with some modifications. At times rust resistance genes can also be characterized through genetic linkage, molecular markers, cyto-genetic analysis and morphological markers. Gene complexes viz. Lr26/Sr31/Yr9/Pm8, Lr20/ Sr15, Lr34/Yr18/ Sr57/Pm38/ Lrt1,Lr46/Yr29/ Sr58/ Pm39/Lrt2,Lr67/Sr55/Yr46/Lrt3, Sr2/Yr30, Sr24/Lr24, Sr25/Lr19, Sr38/Lr37/Yr17, are identified on the bases of tight genetic linkage. These resistance genes are tightly linked, hence presence of one is sufficient for showing the presence of counterpart. Gupta and Saini (1987) postulated the presence of $L r 13$ in 64 exotic wheat lines using Ne2-Lr13 linkage pattern. Nagarajan et al. (1987) documented rust resistance genes in wheat material, subsequently updates were also published (Nayar et al., 2001; and Bhardwaj et al., 2010a, Bhardwaj, 2011).

\section{Genetics of rust resistance in Indian wheat}

Information on genetic of wheat rust resistance is widely available. Recently we have applied known markers for some genes to know the status of some rust resistance genes. In some of the lines we could identify Sr2, Sr28 conferring black rust resistance whereas Lr24, Lr34, Lr68 were also confirmed in some lines. Based on the available information it can be concluded that brown rust resistance of Indian wheat is based on Lr1, Lr2a, Lr3, Lr9, Lr10, Lr13, Lr14a, Lr17, Lr18, Lr19, Lr22a, Lr23, Lr24, Lr26, Lr28, Lr34,Lr46, Lr67 and Lr68 (Nayar et al, 2001; Nagarajan et al., 1987; Bhardwaj et al., 2010a, Bhardwaj, 2011). Among these $L r 26, L r 13, L r 23$ and $L r 34$ have been characterized in many wheat lines. Durum wheat has resistance mainly based on $L r 23$ and $L r 18$ in few cases. Presently Lr24, Lr25, Lr29, Lr32, Lr39, Lr45 and Lr47 are resistant to all the pathotypes of $P$. triticina in India.

Sr2, Sr5, Sr6, Sr7a, Sr7b, Sr8a, Sr8b, Sr9b, Sr9e, Sr11, Sr12, Sr13, Sr17, Sr21, Sr24, Sr28, Sr30 and Sr31 have been characterized in Indian wheat material (Nagarajan et al., 1987; Nayar et al., 2001; Bhardwaj, 2011). Among these Sr2, Sr11 and Sr31 were very common in bread wheat whereas Sr7b, Sr9e and Sr11 conferred black rust resistance in many durum lines. Sr26, Sr27, Sr31, Sr32, Sr33, Sr35, Sr39, Sr40 and Sr43 confer resistance against Indian population of $P$. graminis tritici.

Yellow rust resistance of wheat in India is based on Yr2, YrA, Yr9 and Yr18 (Nagarajan et al., 1987; Wellings et al., 1988; Nayar et al., 2001; Bhardwaj, 2011). Yr5, Yr10, Yr11, Yr12, Yr13, Yr14, Yr15 and Yr16 are resistant against $P$. striiformis in India.

\section{Other recent innovations}

Wheat rusts though obligate parasites, have been cultured. There have been much investigations into race specific, non race specific, slow rusting and adult plant resistance. Lot many resistance gene introgressions and gene pyramiding have been put into action. Landmark invention was to replace $1 \mathrm{BL}$ arm of wheat chromosome by $1 \mathrm{RS}$ of rye during 1930s and its introgression to wheat in 1973. Varieties having this translocation ( $L r 26 / S r 31$ ) Yr9) came up in early eighties which revolutionized the 
wheat production and conferred rust resistance worldwide. It was thought that the problem of wheat rusts has been solved through these, however, virulence of brown rust was identified within three years of its cultivation (Nayar et al., 1991). These varieties became susceptible to Yr9 virulences of yellow rust in Africa, China, Europe, South America by 1985 and to black rust in 1998 (popularly called as Ug99 with virulence to Sr31). Consequently, there had been efforts to enrich the rust resistance gene pool by using primary, secondary and tertiary gene pool. Wheat rust pathogens have neutralized most of the vertical resistance gene used. Growing impetus is to develop wheat varieties with more than one effective rust resistance gene and those having durable rust resistance genes. Some of the rust resistance genes confer tolerance and do not let the yield penalty to occur, are being used in breeding wheat varieties. There is a continuous search for identifying and introgessing novel genes and develop wheat varieties with two or more effective rust resistance genes. It will not only impart durability for rust resistance but would also discourage the occurrence of new pathotypes of Puccinia species on wheat. Recently we have identified a new race specific type of $L r$ gene from a local accession collected from Himachal Pradesh. This gene is located on 2DS chromosome of wheat and is distinct from the already known $L r$ genes both genotypically and phenotypically. It confers resistance to all the predominant and virulent pathotypes of $P$. triticina in India. It has been tentatively designated as $L r L W H$.

Over the years there is strong communication between wheat rust Scientists. Under Borlaug Global Rust Initiative (BGRI), the whole wheat rust family has come together under one umbrella. There are concerted efforts on gene mining, discovery and deployment. More than $210 \mathrm{Lr}$, Sr and Yr genes have been catalogued. Wheat rust genetics has become very precise, clear with many known linked traits. Breeding methodologies for rust resistance have become refined and more result oriented. Marker assisted breeding (like SNPs or other DNA based markers), doubled haploid technique and advancing generation in summer crop at Wellington and Lahaul \& Spiti has reduced the varietal development duration. Many QTLs are known to confer yield/rust resistance traits. Recently many publications have appeared on effectors based resistance in wheat rusts. Genome sequences of wheat brown rusts and yellow rust (Kiran et al., 2017) have been decoded. Exploring the functional genomics and alternative approaches using next generation techniques, would help in effective and efficient management of wheat rusts. Developing of plant bodies (animal origin) based transgenics is known against few diseases. Use of SAR, ISR by the application of Effectors, Transcription factors, PR protein, RNAi, VIGS, Genome editing, Genome wide selection, MAS, Gene cassettes and epigenetics are going to be main technologies for managing the wheat diseases in future.

Invention of Berberis species as alternate hosts for yellow rust in USA in 2010, resulted in further interest in alternate hosts for wheat rusts. We investigated this aspect was again investigated using the published methodology. However, in India and Nepal, Berberis was not found to play any role in the epidemiology of wheat rusts. Wheat rust epidemiology is not clear in countries like India, Australia and many other countries where Berberis is not functional. For yellow rust alone there are more than three hundred grass species which serve as collateral hosts. Our investigations have also hinted on some of the grasses as collateral hosts of wheat rusts. But rusts are very tricky pathogens. Under severe summer and winter these survive in the grasses as mycelium but cannot be seen from outside. Uredospores are produced on grasses twice in a year, once in cool winters and other in rainy season. Therefore, we are trying to identify the latent infection with the help of race specific markers. Most of the grass samples from Northern India have sown negative results.

\section{Management of wheat rusts}

Wheat rust management is a model and exemplary system for other pathogens. Lesson learnt over the time globally is that we can manage the wheat rusts but cannot eradicate and better we learn to live with them and use all the available tools to minimize the losses caused by wheat rusts. Strong coordinated rust monitoring programme, identification of new pathotypes in initial stages and anticipatory rust breeding programme is in place. We had no wheat rust epidemic for the last four decades. Before a new virulent strain becomes predominant, rust resistant material is ready to neutralize it. But continuous monitoring of wheat rust pathogens and breeding is required to keep the wheat rusts below threshold. Vigil through survey surveillance for wheat rusts under All India Coordinated Wheat and Barley Research programme provides the substance for action plan. At the same time efforts would go on for identifying effective and safe chemicals for control of wheat rusts under contingency conditions. As and when there is a report of wheat rust incidence, local application of fungicides like Propiconazole $(0.1 \%)$ is resorted to destroy the initial inoculum at the source itself. A very good network with a fast communication is in place. Wheat rust samples collected in surveys are analyzed for pathotype identification in Regional Station of IIWBR, Flowerdale, Shimla, H.P., a centre dedicated for wheat rust research for the last 95 years. New pathotypes and rust resistance sources are identified well before these become predominant. All the Advance Wheat lines are evaluated for rust resistance against an array of pathotypes and wheat breeding programmes are oriented to deal with the ever changing pathotype situation. Genetic diversity for rust resistance is characterized and this information is used for deployment Wheat varieties keeping in mind the pathotype situation in different areas (Bhardwaj et al., 2016a; Tomar et al., 2014). The outcome is in front of us that we had no wheat rust epidemic for the last 43 years.

\section{REFERENCES}

Anonymous (1992). The wheat rust patrol-striking a fast moving target. Partners in Research for Development. No. 5: 20- 
21. ACIAR, GPO Box 1571, Canberra, ACT, 2601, Australia.

Bhardwaj SC (2011). Resistance genes and adult plant resistance of released wheat varieties of India. Res. Bull. No. 5: 31 pp. Regional Station, Directorate of Wheat Research, Flowerdale, Shimla -171002 HP. India.

Bhardwaj SC (2013). Puccinia-Triticum interaction: an update. Indian Phytopath. 66: 14-19.

Bhardwaj SC, Nayar SK, Prashar M and Kumar J (1989). Occurrence of a new virulent form 117-1 in race 117 of Puccinia graminis f.sp. tritici in India. Cereal Rusts and Powdery Mildews Bulletin 17: 1-5.

Bhardwaj SC, Nayar SK, Prashar M, Kumar J, Menon MK and Singh SB (1990). A pathotype of Puccinia graminis f.sp. tritici on Sr24 in India. Cereal Rusts and Powdery Mildews Bulletin 18: 35-38.

Bhardwaj SC, Prashar M, Kumar S, Jain SK and Datta D (2005). Lr19 resistance in wheat becomes susceptible to Puccinia triticina in India. Plant Dis. 89: 1360.

Bhardwaj SC, Prashar M, Kumar S, Jain SK, Datta D and Kalapannavar I (2006). Two new pathotypes 29R45 and 93R39 of Puccinia triticina from India. Indian Phytopath. 59: 486-488.

Bhardwaj SC, Prashar M, Jain SK, Sharma YP, Kumar S, Singh SB, Singh AK and Chatrath R (2009). Gehun Ke Ratua Rog-parichya, Shodh Satar Avam Prabhandhan (Hindi). Research Bulletin No. 4: 28 PP. Regional Station, Directorate of Wheat Research, Flowerdale, Shimla 171002, H.P. India.

Bhardwaj SC, Prashar M, Jain SK, Kumar Subodh, Sharma YP, Sivasamy M and Kalappanvar IK (2010). Virulence on Lr28 in wheat and its relation to prevalent pathotypes in India. Cereal Res. Commun. 38: 83-89.

Bhardwaj SC, Prashar M, Jain SK, Kumar Subodh and Datta D (2010a). Adult plant resistance in some Indian wheat genotypes and postulation of leaf rust resistance genes. Indian Phytopath. 63: 174-180.

Bhardwaj SC, Prashar M and Prasad P (2014). Ug99-Future Challenges. In: A. Goyal and Manoharachary C (eds.), Future Challenges in Crop Protection against fungal pathogens, Fungal Biology. Springer Science and Business Media, New York, pp. 231-248.

Bhardwaj SC, Prashar M, Kumar Subodh, Gangwar OP, Gupta Neha, Prasad P and Khan H (2016). Patterns of physiologic diversity of Puccinia triticina on wheat in Indian subcontinent during 2008-2013. Indian J. agr. Sci. 86: 5564.

Bhardwaj Subhash C, Prasad Pramod, Gangwar Om P, Khan Hanif and Kumar Subodh (2016a). Wheat rust researchthen and now. Indian J. agr. Sci. 86: 1231-1244.

Biffen RH (1905). Mendel's law of inheritance and wheat breeding. J. Agri. Sci. 1: 4-48.

Browder LE (1973). Probable genotype of some Triticum aestivum 'Agent' derivatives for reaction to Puccinia recondita f. sp. tritici. Crop Sci. 13: 203-206.

Datta D, Prashar M and Bhardwaj SC (2007). Genetic analysis of adult plant leaf rust resistance in three bread wheat (Triticum aestivum L.) cultivars. Euphytica 154: 75-82.

Datta D, Nayar SK, Bhardwaj SC, Prashar M and Kumar Subodh (2008). Detection and inheritance of leaf rust resistance in common wheat lines Agra Local and IWP 94. Euphytica 159: 343-351.

Datta D, Prashar M and Bhardwaj SC (2010). Dissection of genetic factors underlying rust resistance of widely grown wheat (Triticum aestivum) cultivar PBW 343. Ind. J. Agr. Sci. 80: 101-105.

Flor HH (1942). Inheritance of pathogencity in Melampsora lini. Phytopathology 32: 653-669.

Flor HH (1971). Current status of the gene-for-gene concept. Ann. Rev. Phytopathol. 9: 275-296.

Gupta AK and Saini RG (1987). Frequency and effectiveness of $L r 13$ in conferring wheat leaf rust resistance in India. Curr. Sci. 56: 417-419.

Jain SK, Prashar M, Bhardwaj SC, Singh SB and Sharma YP (2009). Emergence of virulence to Sr25 of Puccinia graminis tritici on wheat in India. Plant Dis. 93: 840.

Jain SK, Bhardwaj SC, Prashar M and Singh SB (2013). Physiologic specialization and new virulences of Puccinia graminis f. sp. tritici causing black rust of wheat in India during 2005-2009. Indian J. Agr. Sci. 83: 1058-1063.

Jin Y, Szabo LJ and Carson M (2010). Century-old mystery of Puccinia striiformis life history solved with the identification of Berberis as an alternate host. Phytopathology 100: 432435.

Kiran Kanti, Rawal Hukam C, Dubey Himanshu Jaswal, Rajdeep, Bhardwaj Subhash, Prasad, Pramod, Pal, Dharam, Devanna, B.N. and Sharma, Tilak (2017). Dissection of genomic features and variations of three pathotypes of Puccinia striiformis through whole genome sequencing. Scientific Reports 7: 1-16.

Knott DR (1989). 'The Wheat Rusts-Breeding for Resistance.' Monographs on Theoretical and Applied Genetics 12. (Springer Verlag: Berlin.)

Mclntosh RA, Wellings CR and Park RF (1995). Wheat rust- an atlas of resistance genes. CSIRO Publications, Canberra, Australia. 205 pp.

Mehta KC (1929). Annual recurrence of rusts on wheat in India. Presidential address (Sec. of Botany). Proc. 16th Indian Sci. Congr. 199 pp.

Mehta KC (1940). Further studies on Cereal Rusts in India. Imperial Council Agric. Res. New Delhi Sci. Monogr. 14: $224 \mathrm{pp}$.

Mehta KC (1952). Further Studies on Cereal Rusts in India. Imperial Council Agric. Res. New Delhi Sci Monogr 18: $165 \mathrm{pp}$.

Nagarajan S (2012). Is Puccinia graminis fsp. tritici virulence Ug99 a threat to wheat production in North Western Plain Zone of India. Indian Phytopath. 65: 219-226.

Nagarajan S and Joshi LM (1975). Historic account of wheat rust epidemics in India and their significance. Cereal Rusts Bull. 3: 25-33.

Nagarajan S and Joshi LM (1980). Further investigations on predicting wheat rusts appearance in Central and Peninsular India. Phytopath. Z. 98: 84-94.

Nagarajan S, Joshi LM, Srivastava KD and Singh DV (1978). Synoptic meteorological conditions in relation to leaf rust spread in northern India. Proc. It international conference Aerobiology, held at Munisch, West Germany, Aug. 1978. pp. 446-51.

Nagarajan S, Nayar SK and Bahadur P (1983). The proposed brown rust of wheat (Puccinia recondita f.sp. tritici) virulence analysis system. Curr. Sci. 52: 413-416.

Nagarajan S, Nayar SK, Bahadur P and Bhardwaj SC (1987). Evaluation of some Indian wheat for $\mathrm{Yr}, \mathrm{Lr}$ and $\mathrm{Sr}$ genes by matching technique and genetic uniformity observed. Cereal Rusts and Powdery Mildews Bull. 15: 53-64.

Nagarajan S and Singh H (1973). Satellite television photography as a possible tool to forecast plant disease spread. Curr. Sci. 42: 273-274. 
Nayar SK, Bhardwaj SC and Prashar M (2003). Slow rusting in wheat. Annu. Rev. Plant Pathol. 2: 271-286.

Nayar SK, Bhardwaj SC, Prashar M and Jain SK (2004). Temperature sensitivity and adult plant resistance of some Lrgenes in Triticum species. Indian Phytopath. 57: 90-91.

Nayar SK, Jain SK, Prashar M, Bhardwaj SC, Kumar S and Menon MK (2003a). Appearance of new pathotype of Puccinia recondite tritici virulent on $L 19$ in India. Indian Phytopath. 56: 196-198.

Nayar SK, Nagarajan S, Prashar M, Bhardwaj SC, Jain SK and Datta D (2001). Revised catalogue of genes that accord resistance to Puccinia species in wheat. D.W.R., Regional Station, Flowerdale, Shimla 171002. 48 pp.

Nayar SK, Prashar M, Kumar J, Bhardwaj SC and Bhatnagar R (1991). Pathotypes of Puccinia recondita f.sp. tritici virulent on Lr26 (1BL. 1RS translocation) in India. Cereal Res. Commun. 19: 327-331.

Patpour M, Hovmoller MS, Justesen AF, Newcomb M, Olivera P, Jin Y, Szabo LJ, Shahin AA, Wanyera R, Habarurema I and Wobibi S (2016). Emergence of Virulence to SrTmp in the Ug99 Race Group of Wheat Stem Rust, Puccinia graminis f. sp. tritici in Africa. Plant Dis. 100: 863.

Person C, Samborski DJ and Rohringer R (1962). The genefor-gene concept. Nature (London) 194: 561-562.

Prasada R (1946). The uredostage of aecidium found on Thalictrum in Simla hills. Curr. Sci. 15: 254-255.
Prasada R (1960). Fight the wheat rusts. Indian Phytopath. 13: 1-5.

Prashar M, Bhardwaj SC, Jain SK and Datta D (2007). Pathotypic evolution in Puccinia striifromis in India during 1995-2004. Australian J. Agr. Res. 58: 602-604.

Prashar M, Bhardwaj SC, Jain SK and Gangwar OP (2015). Virulence diversity in Puccinia striiformis f.sp. tritici causing yellow rust on wheat (Triticum aestivum) in India. Indian Phytopath. 68: 129-133.

Pretorius ZA, Singh RP, Wagoire WW and Payne TS (2000). Detection of virulence to wheat stem rust resistance gene Sr31 in Puccinia graminis f. sp. tritici in Uganda. Plant Dis. 84: 203.

Saini RG, Kaur M, Singh B, Sharma S, Nanda GS, Nayar SK, Gupta AK and Nagarajan S (2002). Genes Lr48 and Lr49 for hypersensitive adult plant leaf rust resistance in wheat (Triticum aestivum L.). Euphytica 124: 365-370.

Stakman EC, Stewart DM and Loegening WQ (1962). Identification of physiological races of Puccinia graminis tritici. U.S. Agric. Res. Serv. ARSE-617: 53 pp.

Tomar SMS, Singh SK, Sivasamy M and Vinod (2014). Wheat rusts in India: Resistance breeding and gene deployment - A review. Indian J. Genet. 74: 129-156.

Wellings CR, Mclntosh RA and Hussain M (1988). A new source of resistance to Puccinia striiformis f.sp. tritici in spring wheats (Triticum aestivum). Plant Breed. 100: 88-96. 